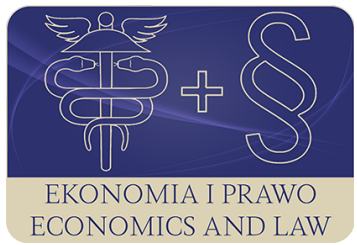

EKONOMIA I PRAWO. ECONOMICS AND LAW Volume 19, Issue 4, December 2020

p-ISSN 1898-2255, e-ISSN 2392-1625

www.economicsandlaw.pl

ORIGINAL ARTICLE

received 30.03.2019; revised 18.03.2020; accepted 31.12.2020

Citation: Kozubek, P.R., (2020). An ex-post analysis of selected road investments in the Świętokrzyskie region in 2007-2016. Ekonomia i Prawo. Economics and Law, 19(4): 713-724. doi:10.12775/EiP.2020.046.

\title{
An ex-post analysis of selected road investments in the Świętokrzyskie region in 2007-2016
}

\author{
PAWEE R. KOZUBEK \\ Kielce University of Technology, Faculty of Management and Computer Modelling, Department \\ of Economics and Finance, Aleja Tysiąclecia PP 7, 25-314 Kielce, Poland \\ $\square$ p.kozubek@tu.kielce.pl \\ (D) orcid.org/0000-0002-4471-0579
}

\begin{abstract}
Motivation: A great number of road investments are currently underway in Poland. Analysing their efficiency requires a range of forecasts and estimates which are not always corroborated by reality. This is due to both objective and subjective causes. Improvements to methods of analysing the efficiency of transport infrastructure investments can be based on ex-post analysis results. These results should serve to eliminate errors and consequently improve the quality of ex-ante analyses.

Aim: The paper aims to identify, based on ex-post analysis, divergences between assumed and real properties of road investments that have key effects on the results of ex-ante efficiency calculus of the investments.

Results: The study was based on selected investments in national and regional roads in the Świętokrzyskie region in 2007-2016. The ex-post analysis has shown that the cap-

ital expenditure and traffic volumes were overestimated, with ADT overestimation reaching nearly as much as $50 \%$ in four cases. Most investments were completed on time. There was a substantial delay in only one case. The overestimations of capital expenditure and traffic volume have a significant impact on the ex-ante evaluation of road investment efficiency, which may lead to misguided decisions when choosing the projects to be completed. The analysis results are a starting point for continuing the research and an indication of the need to improve the quality of ex-ante analyses.
\end{abstract}

Keywords: project evaluation; ex-post analysis; road infrastructure investments JEL: H43; H54; R42; R53 


\section{Introduction}

Several road investments are underway in Poland at present. They involve both the construction of new roads (mainly national, in particular, motorways and expressways) and the modernisation of existing roads (including regional). Road investments are highly capital consuming, therefore, they are predominantly financed from public funds to a large extent co-financed with EU resources.

The need to effectively distribute the limited resources that can be invested in the development of transport infrastructure requires compiling efficiency analyses of the planned investments. The analyses concern two dimensions: economic and financial. The economic evaluation is conducted from the socio-economic perspective. It is essential for transport investments as those failing to prove their economic efficiency cannot be financed with EU funds. The financial evaluation, on the other hand, is undertaken from the investor's point of view and determines the requirement for EU co-financing. Financially efficient projects do not require such support.

The basic methodical assumptions for preparing efficiency analyses of transport investments are contained in national and Community guidebooks, guidelines, method documents, etc. The subsequent, increasingly detailed editions of these compilations over the last ten-odd years have reflected the methodological development of such analyses (Kotowska-Jelonek, 2016, pp. 9-20). The need for improving the methods of efficiency analysis of transport investments has been upheld by research into the divergences in analyses during the previous financing terms, both in other EU countries (Florio \& Vignetti, 2005, pp. 179-210) and in Poland (Kotowska-Jelonek et al., 2008, pp. 3-11). This need was also noted by the International Transport Forum (2011, p. 12).

Risk assessments using quantitative methods like Monte Carlo simulation (European Commission, 2014, pp. 67-76) are integral parts of transport investment efficiency analyses co-financed by the EU. Nonetheless, since there are no adequate data concerning the projects already realised in Poland, national guidelines recommend restricting risk analysis to qualitative aspects (Jaspers, 2015, p. 99).

Improving methods of efficiency analysis regarding transport infrastructure investments has a considerable impact on the reliability of such evaluations. Expost analyses play a major role in this process. Examining the conformity of real and planned data and identifying the scale and causes of divergences between the two should help to eliminate errors and consequently improve the quality of ex-ante analyses. This research also collects data that will be used in quantitative risk analyses of transport infrastructure investments.

This paper aims to identify, based on ex-post analysis, divergences between assumed and real properties of road investments that have key effects on the results of ex-ante efficiency calculus of the investments. The study was based on selected investments in national and regional roads in the Świętokrzyskie region in 2007-2016. The road investments were administered by the Świętokrzyskie 
Region Roads Authority in Kielce and the General Directorate for National Roads and Motorways, Kielce Branch.

\section{Literature review}

An ex-post (retrospective) analysis is carried out upon the completion of the investment or at a certain stage of its execution. It addresses real data and is thus the opposite of ex-ante analysis, based on forecasts and estimates of various magnitudes. An ex-post analysis of investment projects is intended to verify the compliance of real figures, in particular, expenditure and effects, with planned data. Depending on the scope of the analysis, it is subsequently possible to determine the scale and causes of divergences between reality and plans. This should serve to eliminate errors of ex-ante cost-benefit analyses and to minimise risk in the future.

A variety of approaches to ex-post analysis are applied to transport investments, ranging from descriptive (Preston \& Wall, 2008, pp. 403-422) to quantitative methods that attempt to represent the effects of transport investments on diverse macroeconomic quantities, e.g. growth of employment (Duranton \& Turner, 2012, pp. 1407-1440). The Norwegian researchers have distinguished four approaches to ex-post analysis of transport investments (Olsson et al., 2010, pp. 251-252):

- socio-economic evaluation;

- evaluation of the project's business value of a project;

- overall project evaluation;

- evaluation based on the measurement of selected key parameters.

The socio-economic evaluation involves repeating the entire Cost-Benefit Analysis. For example, Kelly et al. (2015, pp. 83-91) have conducted an ex-post CBA of 10 transport (4 rail and 6 road) projects in eight EU countries in 1999-2010. This approach is also employed in relation to large transport projects in the UK, France, and Norway (Meunier \& Welde, 2017, pp. 144-155; Nicolaisen \& Driscoll, 2016, pp. 1-33).

Evaluation of the project's business value involves the assessment of the business outcomes of a project which presents its impact on the investor's finances. In the instance of transport projects, this means the business effects for an infrastructure administrator.

The third approach, overall project evaluation based on a variety of indicators, is a combination of quantitative and qualitative evaluation. It is applied, for example, by the Swedish Institute for Transport and Communications Analysis which, since 1999, every year assesses the extent to which general national objectives for transport and communications systems are reached (Olsson et al., 2010, p. 252). A combination of qualitative and quantitative ex-post analysis also serves to evaluate foreign aid programmes required by institutions financing these programmes. The ex-post evaluation of Measure IV.1 Road Infrastructure 
Under the Operational Programme Development of Eastern Poland 2007-2013 (PARP, 2016) may serve as an example.

The evaluation based on the measurement of selected key parameters involves the identification and measurement of factors that are essential to project efficiency. This approach is common in practice. For instance, Flyvbjerg et al. have studied to what extent ex-ante forecasts correspond to ex-post observations. Their research concerned capital expenditure on 258 large transport infrastructure projects on different continents (Flyvbjerg et al., 2002, pp. 279-295) and traffic forecasts in 210 investments in 14 countries (Flyvbjerg et al., 2005, pp. 131-146). This method is also applied to studying small samples. An example is a study by Olsson et al. (2010, pp. 251-252) who have examined the impact of time of analysis on its results. They addressed 4 railway projects. Punctuality, frequency, travel time, and passenger numbers were compared. Another instance of this type is an analysis of investments in regional roads in Poland: 9 projects in the Świętokrzyskie region (Kozubek, 2017, pp. 235244) and 10 investments in the area of Radom (Szymczak \& Kozubek, 2018, pp. 470-480). Capital expenditure, time of realisation, and scope of investment were reviewed.

Ex-post analyses available in the literature tend to note that optimistic attitudes and exaggeration of benefits coupled with underestimations of capital expenditure are common characteristics of efficiency analyses of transport infrastructure investments (Florio et al., 2018, p. 174). Divergences between forecast and real traffic arise in several projects. For instance, traffic forecasts for 210 projects in 14 countries have been found to contain errors of more than \pm $20 \%$. What is more, forecasting has not become more accurate during the last several decades (Flyvbjerg et al., 2005, p. 140).

Exceeding of scheduled expenditure is another characteristic of transport infrastructure investments. This is especially true of large investments. This is corroborated by Flyvbjerg et al. (2002, p. 282), Kelly et al. (2015, p. 90), among others. For example, a study of 258 large transport investments, including 167 into roads, has discovered capital expenditure on road projects was higher than planned by an average of $20 \%$ (Flyvbjerg et al., 2002, p. 282). The researchers pay particular attention to premeditated understatements of capital expenditure. Such measures are driven by economic considerations, e.g. benefits to designers or contractors, or misinterpreting public interest to mean that lower expenditure saves public funds. They also arise from psychological causes, namely, the emotional commitment of project authors that results in overoptimistic spending estimates. Political aspects are also cited as a major source of such attitudes. Political pressure on those undertaking the forecasts and efficiency analyses leads to understating expenditure in order to carry out investments (Flyvbjerg et al., 2002, pp. 287-290). Purposeful underestimations of capital expenditure produce false evaluations of efficiency and, consequently, lead to the realisation of projects that are not economically viable and the rejection of other projects that might bring greater benefits. Methodological errors, 
e.g. imperfect estimation techniques, problems anticipating the future, the lack of appropriate data, inexperienced contractors are some other sources of errors in spending estimates. Naturally, these causes relate not only to estimates of capital expenditure but also other key project parameters.

\section{Methods}

An ex-post analysis has been conducted, based on the measurement of selected key parameters. This requires the definition of factors to be examined, which are significant to the success of a project.

Experience with feasibility studies of transport infrastructure investments shows that capital expenditure has the ultimate impact on investment effectiveness (Kozubek, 2012, p. 197). Errors in its forecasting constitute a major problem in a range of transport projects. Capital expenditure results from the scope of scheduled work. Extensions to that scope or protracted realisation most frequently increase capital expenditure. The scope of work and time of its realisation are interdependent, too. These three criteria should be considered jointly as part of ex-post analyses. This is the so-called triple constraint theory (Anbari et al., 2008, p. 637).

When an analysis is undertaken several years after the commissioning of an investment, the set of criteria should be expanded with measurements relating to the effects. The efficiency of road investments is determined by socio-economic benefits generated by a project. Their estimation as part of an ex-ante analysis takes into account the volumes of anticipated average daily traffic, the basis for estimating the external benefits of an investment - costs of vehicle operation, road accidents, travel time, air pollution, climate change, and noise (Jaspers, 2015, pp. 47-66).

A comparative analysis of real data and quantities expected in project feasibility studies was used for this research. The scopes of work, timely completion of individual investments, sums of capital expenditure, and average daily traffic (ADT) were compared.

Ten road projects executed in the Świętokrzyskie region, Poland, in 20072016 were examined. The investments for which feasibility studies had been prepared were selected for the analysis. The projects were important for the development of local and regional road networks, while their lengths and scopes of work varied.

The analyses applied to the following projects:

- construction of Małogoszcz ringroad (stage II);

- expansion of Nowa Słupia-Ostrowiec Świętokrzyski section of 751 regional road and construction of Nowa Stupia ringroad;

- rebuilding of Kielce-Staszów-Połaniec 764 regional road at Raków;

- expansion of Staszów-Osiek section of 765 regional road;

- rebuilding of 777 regional road, Lubelska Street in Sandomierz;

- construction of Kielce North Interchange on road 7; 
- construction of S-7 expressway, section Skarżysko-Kamienna-Występa, ringroad of Suchedniów, Ostojów, Łączna, and Występa;

- rebuilding of 12/74 national road up to expressway parameters along the section Kielce-Cedzyna;

- expansion of the existing S7 road up to two-road expressway parameters between Kielce North and Chęciny Interchanges;

- construction of the northern Jędrzejów ringroad along national road 78.

Projects 1-5 concerned regional roads. Their cost ranged from PLN $6.8 \mathrm{~m}$ to PLN 76.5m or between PLN $1.9 \mathrm{~m}$ and PLN $6.2 \mathrm{~m}$ per $1 \mathrm{~km}$. Projects 6-10 applied to national roads. The capital expenditure on those investments ranged from PLN $224.8 \mathrm{~m}$ to PLN $852.5 \mathrm{~m}$ or, stated per $1 \mathrm{~km}$, from PLN $23.2 \mathrm{~m}$ to PLN $52.2 \mathrm{~m}$. The investments were managed by the Świętokrzyskie Region Roads Authority in Kielce and the General Directorate for National Roads and Motorways, Kielce Branch. ADT data from the General Traffic Measurements in 2005, 2010, and 2015 were also used.

Punctuality is a priority in road investments. Default on deadlines normally implies additional costs, some incurred by investors. Feasibility studies and design documents do not always specify start and end dates of construction. These provisions frequently set only the month or even quarter. Completion dates have been adopted to verify the punctuality. Thus, if the start of an investment was delayed but it was then completed on or ahead of schedule, a project was recognised as executed on time.

The total planned capital expenditure and the actual expenditure incurred for a given project were taken into consideration. The expenditure approved by the Ministry of Infrastructure was adopted for analysis in the case of project 9. The spending envisaged by the original feasibility study was approx. $45 \%$ higher and was rejected as excessive.

The average daily traffic (ADT) in Poland is measured every 5 years. In respect of the individual projects, only the years for which ADT was comparable were addressed. The ADT forecast for one project was compared to the 2010 measurements; data for seven projects were derived from the 2015 measurements. Two measurement sections with their separate forecasts, designated la and $\mathrm{lb}$, were covered in the case of project 1 . Project 3 was not subject to analysis as traffic is not measured along that section of the road. Project 9 was excluded as well, as the feasibility study contained ADT over 5 years since 2013, which did not correspond to actual measurements.

The comparisons between capital expenditure and ADT are presented as relative changes; the average relative deviation of real data from forecast data and standard deviation were also computed. 


\section{Results}

Divergences between planned and real capital expenditure are illustrated in table 1 and chart 1 . The table 1 also contains information about conformity between scopes of work and keeping of schedules with comments on the delays.

The investments complied with the anticipated scopes of work. Six investment deadlines were met, while project 2 was completed a month early. Delays in projects 4 and 10 reached 1 month and did not have adverse effects. In the case of project 10, the delay was caused by unexpected archaeological work; an annex delaying the deadline by a month was concluded with the contractor.

If investments on regional (projects 1-5) and national (projects 6-10) roads are compared, delays mostly affected the latter (3 out of 5 investments).

The delays were longest in projects 7 and 9 . These were the two largest road investments in the Świętokrzyskie region in recent years. As far as project 7 is concerned, the 4 months of delay resulted from adverse weather conditions and the discovery of archaeological and animal sites at the time of work. Project 9 was 11 months late. Five annexes were executed with the contractor, once due to a change of VAT rates and four times due to deadline postponement. The contractor argued the completion date needed to be delayed due to the discovery of a 15th century lead mine and adverse weather conditions (heavy rain and freezing winters).

The planned capital expenditure on 9 projects was higher than actually incurred. This means the feasibility studies were $90.0 \%$ likely to overstate the spending. Real capital expenditure constituted $85.4 \%$ of the plans on average, with a standard deviation of $15.27 \mathrm{pp}$. The overestimation exceeded $40 \%$ in $20 \%$ of the investments. Real spending was higher than planned in only $10 \%$ of the cases, though the excess was negligible $(0.09 \%)$.

The overestimations of capital expenditure were chiefly caused by the fact that feasibility studies estimate it based on scopes of work and average market prices. On the other hand, pricing is the key criterion of bids in tender procedures. In addition, lower land prices were negotiated than had originally been assumed. Similar results were shown in earlier research on national road investments in the Świętokrzyskie region (Kozubek, 2017, p. 242) and the area of Radom (Szymczak \& Kozubek, 2018, p. 479).

Divergences between planned and real ADT are illustrated in table 2 and chart 2 . The forecast traffic was greater than anticipated in 5 out of 9 cases, with the overstatement of as much as circa $50 \%$ in 4 projects. In three cases, real ADT was greater than forecast, though the difference was very high, approx. $70 \%$, in one case only. The average real traffic corresponded to $88.07 \%$ of the forecasts, with a standard deviation of $40.59 \mathrm{pp}$.

It can be noted, therefore, that there is excessive optimism about anticipated traffic volumes, particularly with regard to regional roads (projects 2, 4, and 5). This is important since ADT is the key variable in estimating direct and indi- 
rect benefits as part of efficiency analyses of road investments. Overstatements of this quantity produce false ex-ante efficiency evaluations.

\section{Conclusion}

The ex-post analysis of transport infrastructure investment is very important for the accurate assessment of a given project. The absence of feedback on executed investments implies a distinct risk of poor choices in connection with successive investments. This is a serious issue given the high capital consumption and very long periods of infrastructure use.

The research results of selected road investments in the Świętokrzyskie region in 2007-2016 have proved that investments of this type in Poland do not exhibit the characteristic of large transport infrastructure investments, i.e. exceeding the planned capital expenditure and realisation times. The capital expenditure on the projects examined was overestimated by an average of $14.6 \%$. Like in large projects, though, demand is forecast too optimistically. ADT was overestimated by an average of $11.93 \%$, reaching nearly $50 \%$ in 4 cases. The optimistic attitude and overstatement of benefits increases the risk of generating effects, and thus efficiency of an entire investment, differing from those that were anticipated.

Like in several ex-post analyses of even single investments available in the literature (Anguera, 2006, pp. 291-315; Börjesson et al., 2014, pp. 135-148), this study covered a small number of projects. Individual ex-post research provides merely partial evaluations of projects, nonetheless, its results can be utilised to eliminate errors committed in ex-ante analyses.

More systematic ex-post research on road investments in Poland would be advisable. Its results would provide insight into the key elements of road investment efficiency analysis. To this end, the experience from programmes of ex-post studies on transport investments in countries like Norway, France, and the UK may be beneficial.

\section{References}

Anbari, F.T., Carayannis, E.G., \& Voetsch, R.J. (2008). Post-project reviews as a key project management competence. Technovation, 28(10). doi:10.1016/j. technovation.2007.12.001.

Anguera, R. (2006). The channel tunnel: an ex post economic evaluation. Transportation Research Part A: Policy and Practice, 40(4). doi:10.1016/j. tra.2005.08.009.

Börjesson, M., Jonsson, R.D., \& Lundberg, M. (2014). An ex-post CBA for the Stockholm metro. Transportation Research Part A: Policy and Practice, 70. doi:10.1016/j.tra.2014.10.006.

Duranton, G., \& Turner, M.A. (2012). Urban growth and transportation. Review of Economic Studies, 79(4). doi:10.1093/restud/rds010. 
European Commission. (2014). Guide to cost-benefit analysis of investment projects: economic appraisal tool for cohesion policy 2014-2020. doi:10.2776/97516.

Florio, M., Morretta, V., \& Willak, W. (2018). Cost-benefit analysis and European Union cohesion policy: economic versus financial returns in investment project appraisal. Journal of Benefit-Cost Analysis, 9(1). doi:10.1017/ bca.2018.4.

Florio, M., \& Vignetti, S. (2005). Cost-benefit analysis of infrastructure projects in an enlarged European union: returns and incentives. Economic Change and Restructuring, 38(3-4). doi:10.1007/s10644-006-9002-0.

Flyvbjerg, B., Holm, M.K.S., \& Buhl, S.L. (2005). How (in)accurate are demand forecasts in public works projects: the case of transportation. Journal of the AmericanPlanningAssociation, 71(2). doi:10.1080/01944360508976688.

Flyvbjerg, B., Holm, M.S., \& Buhl, S. (2002). Underestimating costs in public works projects: error or lie. Journal of the American Planning Association, 68(3). doi:10.1080/01944360208976273.

International Transport Forum. (2011). Improving the practice of transport project appraisal. ITF round tables, 149. doi:10.1787/9789282103081-en.

Jaspers. (2015). Blue book: road infrastructure. Retrieved 14.02.2020 from https://rpo.opolskie.pl.

Kelly, C., Laird, J., Costantini, S., Richards, P., Carbajo, J., \& Nellthorp, J. (2015). Ex post appraisal: what lessons can be learnt from EU cohesion funded transport projects. Transport Policy, 37. doi:10.1016/j.tranpol.2014.09.011.

Kotowska-Jelonek, M. (2016). Ewolucja metodyki oceny efektywności inwestycji infrastrukturalnych w transporcie wspótfinansowanych z funduszy Unii Europejskiej. Zeszyty Naukowe Uniwersytetu Gdańskiego: Wyzwania Rozwoju Transport: Polityka-Przedsiębiorstwo-Technika, 59.

Kotowska-Jelonek, M., Dyr, T., Zagożdżon, B., \& Kozubek, P.R. (2008). Problemy oceny efektywności kolejowych inwestycji infrastrukturalnych wspólfinansowanych przez Unię Europejską. Przegląd Komunikacyjny, 47(1).

Kozubek, P.R. (2012). Efektywność inwestycji infrastrukturalnych $w$ transporcie kolejowym: analiza i ocena. Kielce: Politechnika Świętokrzyska.

Kozubek, P. R. (2017). Analizy ex post w ocenie efektywności transportowych inwestycji infrastrukturalnych na przykładzie inwestycji drogowych, zrealizowanych w regionie Świętokrzyskim w latach 2005-2013. Zeszyty Naukowe Uniwersytetu Gdańskiego: ekonomika transportu i logistyka: aktualne wyzwania rozwoju transportu, 74.

Meunier, D., \& Welde, M. (2017). Ex-post evaluations in Norway and France. Transportation Research Procedia, 26. doi:10.1016/j.trpro.2017.07.015.

Nicolaisen, M.S., \& Driscoll, P.A. (2016). An international review of ex-post project evaluation schemes in the transport sector. Journal of Environmental Assessment Policy and Management, 18(1). doi:10.1142/S1464333216500083.

Olsson, N.O.E., Krane, H.P., Rolstadas, A., \& Veiseth, M. (2010). Influence of reference points in ex post evaluations of rail infrastructure projects. Transport Policy, 17(4). doi:10.1016/j.tranpol.2010.01.008. 
PARP. (2016). Ewaluacja ex-post dziatania IV.1 Infrastruktura drogowa Programu Operacyjnego Rozwój Polski Wschodniej 2007-2013: raport końcowy. Retrieved 14.02.2020 from https://www.ewaluacja.gov.pl.

Preston, J., \& Wall, G. (2008). The ex-ante and ex-post economic and social impacts of the introduction of high-speed trains in South East England. Planning Practice and Research, 23(3). doi:10.1080/02697450802423641.

Szymczak, P., \& Kozubek, P.R. (2018). Analiza ex-post inwestycji drogowych realizowanych na drogach wojewódzkich $\mathrm{w}$ rejonie radomskim $\mathrm{w}$ latach 2014-2017. Studia i Materiaty: Miscellanea Oeconomicae, 2(2).

\section{Acknowledgements}

Author contributions: author has given an approval to the final version of the article.

Funding: this research was undertaken as part of the Ex-post analyses of transport infrastructure investments in the Świętokrzyskie region project and was fully funded by the Kielce University of Technology, Faculty of Management and Computer Modeling statutory sources.

Note: the results of this study were presented at 10th International Conference on Applied Economics Contemporary Issues in Economy (June 27-28, 2019, Torun, Poland). 


\section{Appendix}

\section{Table 1.}

Results of ex-post research on scopes of investments, capital expenditure, and time of realisation

\begin{tabular}{lccc}
\hline Project & Scope of realisation & Real versus planned capital expenditure (in \%) & Time of construction \\
\hline 1 & compliant & 57.73 & compliant \\
2 & compliant & 59.70 & compliant (1 month ahead) \\
3 & compliant & 100.09 & compliant \\
4 & compliant & 80.04 & delay (1 month) \\
5 & compliant & 87.96 & compliant \\
6 & compliant & 87.47 & compliant \\
7 & compliant & 93.66 & delay (4 months) \\
8 & compliant & 97.64 & compliant \\
9 & compliant & 98.06 & delay (ll months) \\
10 & compliant & 91.60 & delay (l month) \\
\hline
\end{tabular}

Source: Own preparation.

Table 2.

Ex-post research results on road traffic (ADT)

\begin{tabular}{lcc}
\hline \multicolumn{1}{c}{ Project } & Year of ADT measurement & Real ADT in relation to forecast (in \%) \\
\hline la & 2010 & 114.78 \\
$\mathrm{lb}$ & 2010 & 106.24 \\
2 & 2015 & 52.74 \\
4 & 2015 & 52.76 \\
5 & 2015 & 49.62 \\
6 & 2015 & 52.58 \\
7 & 2015 & 90.61 \\
8 & 2015 & 103.63 \\
10 & 2015 & 169.66 \\
\hline
\end{tabular}

Source: Own preparation. 


\section{Chart 1.}

Inaccuracy of estimated capital expenditure (in \%)

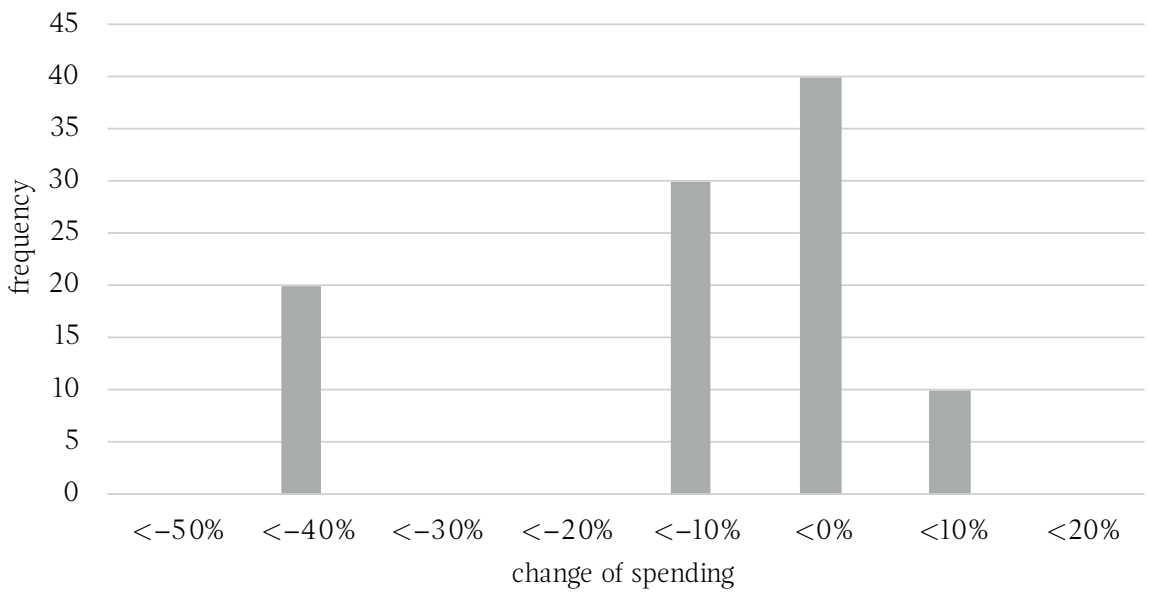

Notes:

Road projects ( $\mathrm{N}=10)$.

Source: Own preparation.

\section{Chart 2.}

Inaccuracy of estimated capital expenditure (in \%)

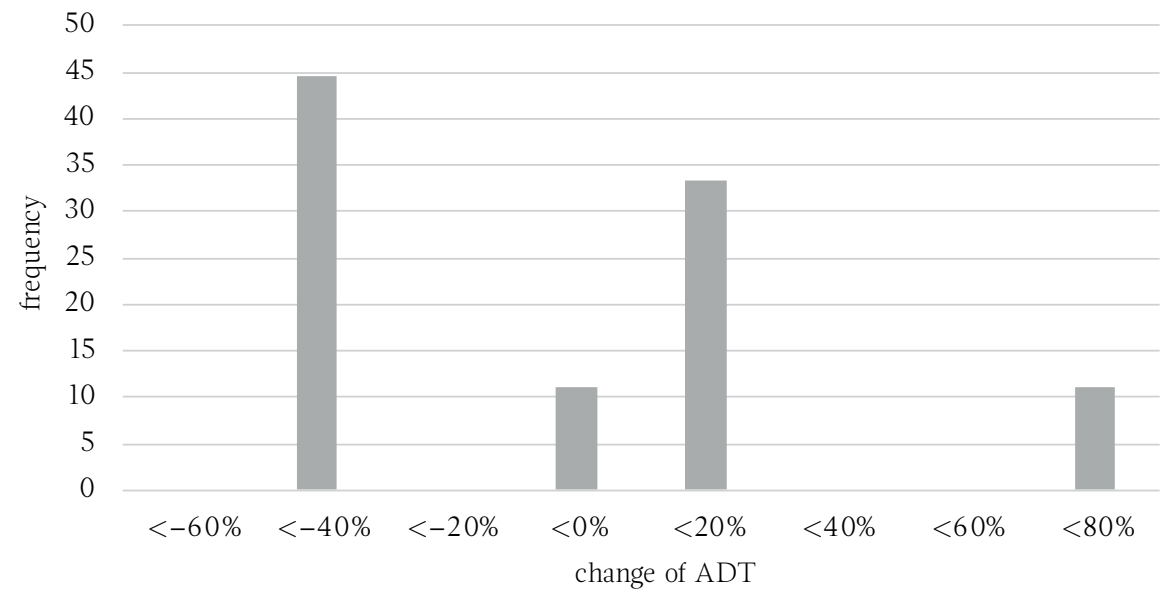

Notes:

ADT measurements $(\mathrm{N}=9)$.

Source: Own preparation. 